\title{
Comparison of Clinical Characteristics and Prognostic Laboratory Findings of COVID-19 Patients by Age Groups
}

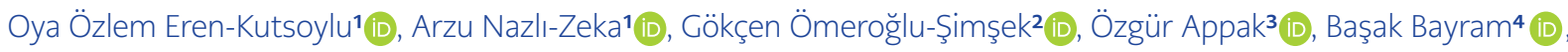

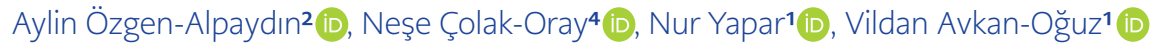 \\ 1 Infectious Diseases and Clinical Microbiology Department, Dokuz Eylül University School of Medicine, İzmir, Turkey \\ 2 Department of Pulmonary Diseases, Dokuz Eylül University School of Medicine, İmir, Turkey \\ 3 Department of Medical Microbiology, Division of Medical Virology, Dokuz Eylül University School of Medicine, Izmir, Turkey \\ 4 Department of Emergency Medicine, Dokuz Eylül University School of Medicine, İzmir, Turkey
}

\begin{abstract}
Objective: In this study, we determined the symptoms of the COVID-19 and defined agespecific symptoms that can help diagnose the disease on hospital admission.

Materials and Methods: Patients who visited a university hospital's adult pandemia outpatient clinic with suspected COVID-19 symptoms and tested with SARS-CoV-2 polymerase chain reaction test between March 17 - May 17, 2020, were included in the study. Demographic data, symptoms on admission, prognostic laboratory tests and hospitalization were recorded.

Results: Out of 5289 admissions, 639 (12.1\%) patients had suspected or confirmed COVID-19. Patients were sorted incident to age groups to determine the difference in demographic data, comorbidities, symptoms, prognostic laboratory findings and outcome. The exposure history was lower in the 65-79 age group, contrary to the $\geq 80$ age group. Sore throat, loss of smell and taste, headache and myalgia were specific to the $18-49$ age group $(p<0.001)$. Shortness of breath was represented 2.31 and 2.79 times higher in the 65-79 and the $\geq 80$ age group, respectively, than the 18-49 age group. Comorbid diseases, prognostic laboratory tests (lymphopenia, C-reactive protein (CRP), D-dimer, ferritin) and hospitalization were found significantly higher in the $\geq 65$ age group than the 18-49 age group.

Conclusion: This study identifies the varieties in comorbidities, symptoms, prognostic laboratory findings and outcomes between the age-grouped patients referred to the outpatient clinic with suspected or confirmed COVID-19. We found that comorbidities, poor prognostic factors and hospitalization are more common in patients over 65 years. Shortness of breath is the most common symptom seen in the $\geq 65$ age group compared to the 18-49 age group, where sore throat, loss of taste and smell are the symptoms commonly seen. Predominant symptoms for age groups help physicians differentiate the disease in clinical practice.
\end{abstract}

Keywords: COVID-19, SARS-CoV-2, age groups, clinical features, prognosis
Corresponding Author:

Oya Özlem Eren-Kutsoylu

E-mail:

oyaeren76@yahoo.com

Received: August 15, 2021

Accepted: October 6, 2021

Published: December 30, 2021

\section{Suggested citation:}

Eren-Kutlusoy OÖ, Nazlı-Zeka A, Ömeroğlu-Şimşek G, Appak Ö, Bayram B, Özgen-Alpaydın $A$, et al. Comparison of clinical characteristics and prognostic laboratory findings of COVID-19 patients by age groups. Infect Dis Clin Microbiol 2021; 3: 120128.

DOI: 10.36519/idcm.2021.76 


\section{INTRODUCTION}

Se evere acute respiratory syndrome coronavirus 2 (SARS-CoV-2) causes the disease called the coronavirus disease 2019 (COVID-19). The World Health Organization (WHO) declared COVID-19 as a pandemic on March 11, 2020, and on the same day, the Republic of Turkey Ministry of Health declared the first COVID-19 patient in our country. There were 250,333,159 cases and 4,333,094 deaths worldwide till August 15, 2021 (1). In our country, total cases and deaths were $6,018,485$ and 52,703, respectively, and the cases and deaths gradually increased as the third peak started (2).

The disease is manifested by a broad spectrum of symptoms from asymptomatic to severe illness that can lead patients to death. Although there are some common symptoms, patients state various symptoms, including most human body organ systems. The most common symptoms of COVID-19 at hospital admission are cough, fever, myalgia, loss of smell and taste, shortness of breath and fatigue (3-8). In addition to these symptoms, patients considerably stated headache, nausea, vomiting, diarrhea. Currently, there are few studies about COVID-19 symptoms defined by specific age groups (9).

It was a dilemma to differentiate COVID-19 patients from other respiratory tract infections with symptoms on hospital admission as a newly defined disease. However, if specific age-related symptoms can be demonstrated, it will be easier to diagnose these patients at hospital admission.

In this paper, we aimed to determine the symptoms of the COVID-19 and define age-specific symptoms and prognostic laboratory tests, which can be helpful to diagnose the disease on hospital admission.

\section{MATERIALS AND METHODS}

This retrospective, cross-sectional study included patients who visited an adult pandemia outpatient clinic of a 1000-bed university hospital with suspected COVID-19 symptoms dates between March 17 - May 17, 2020. Patients 18 years and older who were also tested for SARS-CoV-2 PCR were included in the study. Medical records were examined to fill data collection forms. Demographic data regarding the gender and age of the patient, the information regarding the contact with confirmed/suspected patients (exposure history), smoking status, comorbidities, symptoms on admission (fever, fatigue, myalgia, loss of taste and smell, sore throat, headache, cough, difficulty in breathing, chest pain, nausea, vomiting, diarrhea), laboratory tests [total blood count, C-reactive protein (CRP), ferritin, D-dimer, troponin, procalcitonin and real-time polymerase chain reaction (RT-PCR)], imaging characteristics and hospitalization were recorded.

Lymphopenia, CRP, ferritin, D-dimer and troponin were accepted prognostic factors as defined in the Republic of Turkey Ministry of Health COVID-19 Treatment Guideline (10).

\section{Statistical Analysis}

Statistical analysis was performed using the 15.0 version of the Statistical Package for the Social Sciences (SPSS) program (IBM, Armonk, NY, USA). Age groups were defined as follows: 18-49 years, 50-64 years, 65-79 years and $\geq 80$ years (11). Chisquare analysis was used to identify the difference in comorbidities, symptoms and prognostic factors within age groups. Odds ratios (ORs) and 95\% confidence intervals (CIs) were calculated using univariate logistic regression to measure the association between age groups and sex, exposure history, comorbidities, symptoms, prognostic factors and hospitalization of COVID-19 patients. Multivariate logistic regression analysis was used to determine the factor affecting treatment, hospitalization and intensive care unit (ICU)

\section{HIGHLIGHTS}

- Sore throat, loss of smell and taste, headache and myalgia are more specific to ages between 18 and 49 .

- Shortness of breath is more specific to patients over 65 years.

- Predominant symptoms for age groups can help physicians differentiate the disease in clinical practice and can also be helpful to identify the disease in outpatient clinics and speed up the transfer of the patients to pandemic areas. 
admission. Independent variables with $p$ values $<0.05$ in the univariate analysis [age, sex and presence of comorbidity, diabetes mellitus (DM), chronic heart disease, chronic lung disease] were included in the multivariate model.

\section{RESULTS}

Within the study period, a total of 5289 outpatient clinic admissions were reported. The number of suspected or confirmed COVID-19 patients was 639 (12.1\%). Out of 639 patients, 326 (51\%) were female, and the median age was $48 \pm 21.3$ years (range: 18 101). Seventy (11\%) patients were healthcare workers (HCW). Among HCWs, 56 (80\%) were in the 18-49 age group, and one (1.4\%) was over 65 years old.

Three hundred and two (47.3\%) patients indicated contact with a COVID-19 patient. Demographic data of the patients were given in Table 1. Patients aged 65 to 79 years had $73 \%$ less exposure history than patients 18-49 years old (Table 2). Forty-two $(60 \%)$ of HCWs had an exposure history. Of the patients over 80 years, 76 (76\%) were residents of nursing homes, and most of them had an exposure history, but in the 65-79 age group, only 37 (37.7\%) were living in nursing homes. Out of 639 patients, 532 (83.3\%) were symptomatic. Fever, cough and shortness of breath were the most common symptoms on admission. Among 107 asymptomatic patients, 98 (91.6\%) tested positive for SARS-CoV-2 in PCR.

Out of 444 patients, 47 (10.6\%) were smokers, and 37 (8.3\%) had a smoking background (Table 1). Thirty-seven (78.7\%) smokers belonged to the 18-49 years age group, and seven (18.9\%) of them were HCWs.

Patients were sorted incident to age groups to determine the difference in demographic data, comorbidities, symptoms, prognostic laboratory findings and outcome.

Comorbidities of the patients according to age groups are shown in Table 2. Among HCWs, 16 (22.9\%) had at least one comorbidity, and DM was the most common.
Table 1. Demographic data of COVID-19 patients admitted to the pandemic outpatient clinic.

\begin{tabular}{|c|c|}
\hline & $\mathrm{n}=639(\%)$ \\
\hline \multicolumn{2}{|l|}{ Age } \\
\hline $18-49$ & $334(52.3)$ \\
\hline $50-64$ & $107(16.8)$ \\
\hline $65-79$ & $98(15.3)$ \\
\hline$\geq 80$ & $100(15.6)$ \\
\hline \multicolumn{2}{|l|}{ Gender } \\
\hline Female & $326(51.0)$ \\
\hline Male & $313(49.0)$ \\
\hline Healthcare worker & $70(11.0)$ \\
\hline \multicolumn{2}{|l|}{ Smoking } \\
\hline Smoker & $47(10.6)$ \\
\hline Non-smoker & 397 (89.4) \\
\hline Comorbidities & $304(47.6)$ \\
\hline Hypertension & $180(28.2)$ \\
\hline Diabetes mellitus & $85(13.3)$ \\
\hline Chronic heart disease & $60(9.4)$ \\
\hline Chronic lung disease & $52(8.1)$ \\
\hline Malignancy & $25(3.9)$ \\
\hline Neurologic disease & $17(2.7)$ \\
\hline Chronic renal failure & $14(2.2)$ \\
\hline \multicolumn{2}{|l|}{ COVID-19 } \\
\hline PCR positive & $464(72.6)$ \\
\hline PCR negative & $175(27.4)$ \\
\hline History of COVID-19 exposure & $302(47.3)$ \\
\hline
\end{tabular}

There was no statistically significant difference in terms of symptom existence between age groups. The distribution of symptoms according to age groups was given in Table 3. Fever, sore throat, cough were the most frequent symptoms of HCWs. Sore throat, loss of smell and taste, headache and myalgia were specific to the 18-49 age group $(p<0.001)$. Shortness of breath was represented 2.31 and 2.79 times higher in the 65-79 years and $\geq 80$ years age group, respectively, than the 18-49 years age group. 
Table 2. Distribution of demographic data of COVID-19 patients admitted to the pandemic outpatient clinic by age groups.

\begin{tabular}{|c|c|c|c|c|}
\hline $\begin{array}{l}\text { Age } \\
\text { groups }\end{array}$ & $\begin{array}{c}\text { Female } \\
n(\%) \\
\text { OR }(95 \% \mathrm{Cl})\end{array}$ & $\begin{array}{c}\text { Exposure } \\
n(\%) \\
\text { OR }(95 \% \mathrm{Cl})\end{array}$ & $\begin{array}{c}\text { Comorbidities } \\
n(\%) \\
\text { OR }(95 \% \mathrm{Cl})\end{array}$ & $\begin{array}{c}\text { Diabetes mellitus } \\
\mathrm{n}(\%) \\
\text { OR }(95 \% \mathrm{Cl})\end{array}$ \\
\hline $\begin{array}{l}18-49 \\
\text { (ref.) }\end{array}$ & $\begin{array}{c}157(47.0) \\
1\end{array}$ & $\begin{array}{c}199(59.6) \\
1\end{array}$ & $\begin{array}{c}64(19.2) \\
1\end{array}$ & $\begin{array}{c}10(2.3) \\
1\end{array}$ \\
\hline $50-64$ & $\begin{array}{c}56(52.3) \\
1.23(0.80-1.91)\end{array}$ & $\begin{array}{c}55(51.4) \\
0.67(0.41-1.10)\end{array}$ & $\begin{array}{c}63(53.8) \\
6.04(3.76-9.68)\end{array}$ & $\begin{array}{c}19(17.7) \\
6.99(3.14-15.58)\end{array}$ \\
\hline $65-79$ & $\begin{array}{c}53(54.1) \\
1.32(0.84-2.08)\end{array}$ & $\begin{array}{c}24(24.5) \\
0.27(0.15-0.49)\end{array}$ & $\begin{array}{c}84(85.7) \\
25.31(13.50-47.43)\end{array}$ & $\begin{array}{c}30(30.6) \\
14.29(6.67-30.62)\end{array}$ \\
\hline $80+$ & $\begin{array}{c}60(60.0) \\
1.69(1.07-2.66)\end{array}$ & $\begin{array}{c}67(67.0) \\
1.13(0.50-2.55)\end{array}$ & $\begin{array}{c}93(93.0) \\
56.04(24.80-126.63)\end{array}$ & $\begin{array}{c}26(26.0) \\
11.38(5.26-24.63)\end{array}$ \\
\hline$p$ & 0.017 & 0.009 & $<0.001$ & $<0.001^{*}$ \\
\hline $\begin{array}{l}\text { Age } \\
\text { groups }\end{array}$ & $\begin{array}{c}\text { Chronic heart disease } \\
n(\%) \\
\text { OR }(95 \% \mathrm{Cl})\end{array}$ & $\begin{array}{c}\text { Chronic lung disease } \\
n(\%) \\
\text { OR }(95 \% \mathrm{Cl})\end{array}$ & $\begin{array}{c}\text { Neurologic disease } \\
n(\%) \\
\text { OR }(95 \% \mathrm{Cl})\end{array}$ & $\begin{array}{c}\text { Malignancy } \\
n(\%) \\
\text { OR }(95 \% \mathrm{CI})\end{array}$ \\
\hline $\begin{array}{l}\begin{array}{l}18-49 \\
\text { (ref.) }\end{array} \\
\text { (res }\end{array}$ & $\begin{array}{c}26(7.8) \\
1\end{array}$ & $\begin{array}{c}9(2.7) \\
1\end{array}$ & $\begin{array}{c}2(0.6) \\
1\end{array}$ & $\begin{array}{c}1(0.3) \\
1\end{array}$ \\
\hline $50-64$ & $\begin{array}{c}30(28.0) \\
4.61(2.58-8.25)\end{array}$ & $\begin{array}{c}11(10.3) \\
4.13(1.66-10.27)\end{array}$ & $\begin{array}{c}1(0.9) \\
3.16(0.44-22.72)\end{array}$ & $\begin{array}{c}5(4.7) \\
16.32(1.88-141.32)\end{array}$ \\
\hline $65-79$ & $\begin{array}{c}67(68.4) \\
25.60(14.27-45.92)\end{array}$ & $\begin{array}{c}22(22.4) \\
10.45(4.62-23.61)\end{array}$ & $\begin{array}{c}5(5.1) \\
17.68(3.56-79.08)\end{array}$ & $\begin{array}{c}15(15.3) \\
60.18(7.83-462.12)\end{array}$ \\
\hline $80+$ & $\begin{array}{c}72(72.0) \\
30.46(16.84-55.07)\end{array}$ & $\begin{array}{c}9(9.0) \\
3.57(1.37-9.26)\end{array}$ & $\begin{array}{c}9(9.0) \\
141.40(33.34-599.60)\end{array}$ & $\begin{array}{c}4(4.0) \\
13.87(1.53-125.60)\end{array}$ \\
\hline$p$ & $<0.001$ & $<0.001^{*}$ & $<0.001$ & $<0.001^{*}$ \\
\hline
\end{tabular}

* chi-square for trend

Data analyzed according to the prognostic laboratory values defined in the Republic of Turkey Ministry of Health COVID-19 Diagnosis and Treatment Guideline is presented in Table 4.

Among HCWs, 56 (80\%) were given treatment, 16 (22.9\%) were hospitalized, and one HCW was admitted to ICU and deceased. Outcome data of the patients using univariate analysis are given in Table 5 .

As a result of multivariate logistic regression analysis, it was determined that age significantly affected receiving treatment, hospitalization, and intensive care unit admission, even after correcting for gender, underlying disease, DM, chronic heart disease, and presence of chronic lung disease.

When the patients who received treatment were evaluated, it was observed that more treatment was given to other age groups compared to the 18-
49 age group. It was determined that the adjusted OR increased to 2.89 in the 50-64 age group, 3.95 in the 65-79 age group, and 7.37 in the 80 and over age group $(95 \% \mathrm{CI}=1.38-6.05,95 \% \mathrm{CI}=1.57-9.93,95 \% \mathrm{CI}=$ 2.37-22.88, respectively).

Similarly, when hospitalized patients were evaluated, the OR was 3.37 (95\% CI=2.06-5.53) in the 50-64 age group and 8.06 (95\% CI=4.30-15.17) in the 65-79 age group. The adjusted OR increased to 12.71 (95\% $\mathrm{CI}=6.25-25.84)$ in the patient group aged 80 years and over.

It was observed that the adjusted OR decreased to 7.75 in the $65-79$ age group and 12.33 in the $\geq 80$ age group, but the significance remained (95\% CI=1.5638.56, 95\% CI=2.51-60.49, respectively) in patients hospitalized in the intensive care unit.

This analysis also found that the presence of underlying disease significantly affected hospitaliza- 
Table 3. Distribution of symptoms of COVID-19 patients by age groups.

\begin{tabular}{|c|c|c|c|c|c|c|c|}
\hline $\begin{array}{l}\text { Age } \\
\text { groups }\end{array}$ & $\begin{array}{c}\text { Symptom } \\
\text { existence } n(\%) \\
\text { OR }(95 \% \mathrm{Cl})\end{array}$ & $\begin{array}{l}\text { Fever n (\%) } \\
\text { OR }(95 \% \mathrm{Cl})\end{array}$ & $\begin{array}{l}\text { Cough n (\%) } \\
\text { OR }(95 \% \mathrm{Cl})\end{array}$ & $\begin{array}{l}\text { Shortness of } \\
\text { breath n (\%) } \\
\text { OR }(95 \% \text { Cl) }\end{array}$ & $\begin{array}{c}\text { Fatigue n (\%) } \\
\text { OR }(95 \% \mathrm{Cl})\end{array}$ & $\begin{array}{c}\text { Muscle or body } \\
\text { aches } \mathrm{n}(\%) \\
\text { OR }(95 \% \mathrm{CI})\end{array}$ & $\begin{array}{c}\text { Arthralgia } \\
n(\%) \\
\text { OR }(95 \% \mathrm{Cl})\end{array}$ \\
\hline $\begin{array}{l}18-49 \\
\text { (ref.) }\end{array}$ & $\begin{array}{c}275(82.3) \\
1\end{array}$ & $\begin{array}{c}97(29.0) \\
1\end{array}$ & $\begin{array}{c}124(37.1) \\
1\end{array}$ & $\begin{array}{c}60(18.0) \\
1\end{array}$ & $\begin{array}{c}82(24.5) \\
1\end{array}$ & $\begin{array}{c}32(9.6) \\
1\end{array}$ & $\begin{array}{c}18(5.4) \\
1\end{array}$ \\
\hline $50-64$ & $\begin{array}{c}92(86.0) \\
1.31(0.71-2.43)\end{array}$ & $\begin{array}{c}35(32.7) \\
1.18(0.74-1.89)\end{array}$ & $\begin{array}{c}47(44.0) \\
1.32(0.85-2.06)\end{array}$ & $\begin{array}{c}20(18.7) \\
1.05(0.59-1.83)\end{array}$ & $\begin{array}{c}22(20.6) \\
0.79(0.46-1.35)\end{array}$ & $\begin{array}{c}10(9.3) \\
0.97(0.46-2.05)\end{array}$ & $\begin{array}{c}1(0.9) \\
0.16(0.02-1.25)\end{array}$ \\
\hline $65-79$ & $\begin{array}{c}85(86.7) \\
1.40(0.73-2.68)\end{array}$ & $\begin{array}{c}32(32.6) \\
1.18(0.73-1.92)\end{array}$ & $\begin{array}{c}37(37.7) \\
1.02(0.64-1.63)\end{array}$ & $\begin{array}{c}33(33.7) \\
2.31(1.40-3.83)\end{array}$ & $\begin{array}{c}18(18.4) \\
0.69(0.39-1.22)\end{array}$ & $\begin{array}{c}1(1.0) \\
0.97(0.01-0.72)\end{array}$ & $\begin{array}{c}2(2.0) \\
0.36(0.08-1.60)\end{array}$ \\
\hline $80+$ & $\begin{array}{c}80(80.0) \\
0.85(0.48-1.51)\end{array}$ & $\begin{array}{c}32(32.0) \\
1.15(0.71-1.86)\end{array}$ & $\begin{array}{c}32(32.0) \\
0.79(0.49-1.28)\end{array}$ & $\begin{array}{c}38(38.0) \\
2.79(1.71-4.57)\end{array}$ & $\begin{array}{c}15(15.0) \\
0.54(0.29-0.99)\end{array}$ & $0 \underset{*}{0}$ & $0 \underset{*}{0}$ \\
\hline$p$ & 0.497 & 0.828 & 0.363 & $<0.001^{\star \star}$ & $0.026^{\star \star}$ & $<0.001^{\star \star}$ & 0.016 \\
\hline $\begin{array}{l}\text { Age } \\
\text { groups }\end{array}$ & $\begin{array}{c}\text { Sore throat } \\
n(\%) \\
\text { OR }(95 \% \mathrm{Cl})\end{array}$ & $\begin{array}{c}\text { Headache } \\
n(\%) \\
\text { OR }(95 \% \mathrm{Cl})\end{array}$ & $\begin{array}{c}\text { Loss of taste } \\
n(\%) \\
\text { OR }(95 \% \mathrm{Cl})\end{array}$ & $\begin{array}{c}\text { Loss of smell } \\
n(\%) \\
\text { OR }(95 \% \mathrm{Cl})\end{array}$ & $\begin{array}{c}\text { Nausea or } \\
\text { vomiting } \\
n(\%) \\
\text { OR }(95 \% \mathrm{CI})\end{array}$ & \multicolumn{2}{|c|}{$\begin{array}{c}\text { Diarrhea } \\
n(\%) \\
\text { OR }(95 \% \mathrm{CI})\end{array}$} \\
\hline $\begin{array}{l}18-49 \\
\text { (ref.) }\end{array}$ & $\begin{array}{c}64(19.2) \\
1\end{array}$ & $\begin{array}{c}43(12.9) \\
1\end{array}$ & $\begin{array}{c}21(6.3) \\
1\end{array}$ & $\begin{array}{c}26(7.8) \\
1\end{array}$ & $\begin{array}{c}21(6.3) \\
1\end{array}$ & \multicolumn{2}{|c|}{$\begin{array}{c}13(3.9) \\
1\end{array}$} \\
\hline $50-64$ & $\begin{array}{c}15(14.0) \\
0.68(0.37-1.26)\end{array}$ & $\begin{array}{c}7(6.5) \\
0.47(0.20-1.08)\end{array}$ & $\begin{array}{c}3(2.8) \\
0.43(0.12-1.47)\end{array}$ & $\begin{array}{c}4(3.7) \\
0.46(0.15-1.34)\end{array}$ & $\begin{array}{c}7(6.5) \\
1.04(0.43-2.53)\end{array}$ & \multicolumn{2}{|c|}{$\begin{array}{c}0(0.0) \\
0.00\end{array}$} \\
\hline $65-79$ & $\begin{array}{c}2(2.0) \\
0.88(0.02-0.36)\end{array}$ & $\begin{array}{c}4(4.1) \\
0.28(0.10-0.82)\end{array}$ & $0 \underset{*}{0}(0.0)$ & $\begin{array}{c}1(1.0) \\
0.12(0.01-0.91)\end{array}$ & $\begin{array}{c}9(9.2) \\
1.51(0.67-3.41)\end{array}$ & \multicolumn{2}{|c|}{$\begin{array}{c}3(3.1) \\
0.78(0.22-2.79)\end{array}$} \\
\hline $80+$ & $\begin{array}{c}2(2.0) \\
0.86(0.21-0.35)\end{array}$ & $0 \underset{*}{0}(0.0)$ & $0 \underset{*}{0}(0.0)$ & $0 \underset{*}{0}(0.0)$ & $\begin{array}{c}3(3.0) \\
0.46(0.14-1.58)\end{array}$ & \multicolumn{2}{|c|}{$\begin{array}{c}4(4.0) \\
1.03(0.33-3.23)\end{array}$} \\
\hline$p$ & $<0.001^{\star \star}$ & $<0.001^{\star *}$ & $<0.001^{\star \star}$ & $<0.001^{\star *}$ & 0.354 & \multicolumn{2}{|c|}{0.226} \\
\hline
\end{tabular}

* not calculated due to zero $(0)$ value in one of the cells

** chi-square for trend

Table 4. Distribution of prognostic factors by age groups.

\begin{tabular}{|c|c|c|c|c|}
\hline $\begin{array}{l}\text { Age } \\
\text { groups }\end{array}$ & $\begin{array}{c}\text { Lymphopenia }(\leq 800) \\
n(\%) \\
\text { OR }(95 \% \mathrm{Cl})\end{array}$ & $\begin{array}{c}\text { CRP elevation }(>50) \\
n(\%) \\
\text { OR }(95 \% \mathrm{Cl})\end{array}$ & $\begin{array}{c}\text { D-dimer }(\geq 1) \\
n(\%) \\
\text { OR }(95 \% \mathrm{Cl})\end{array}$ & $\begin{array}{c}\text { Ferritin elevation }(\geq 500) \\
n(\%) \\
\text { OR }(95 \% \mathrm{Cl})\end{array}$ \\
\hline $\begin{array}{l}18-49 \\
\text { (ref.) }\end{array}$ & $\begin{array}{c}72(21.5) \\
1\end{array}$ & $\begin{array}{c}31(9.3) \\
1\end{array}$ & $\begin{array}{c}23(6.9) \\
1\end{array}$ & $\begin{array}{c}5(1.5) \\
1\end{array}$ \\
\hline $50-64$ & $\begin{array}{c}20(18.7) \\
1.19(0.68-2.07)\end{array}$ & $\begin{array}{c}17(15.9) \\
1.84(0.97-3.48)\end{array}$ & $\begin{array}{c}10(9.3) \\
1.39(0.64-3.03)\end{array}$ & $\begin{array}{c}6(5.6) \\
3.90(1.16-13.07)\end{array}$ \\
\hline $65-79$ & $\begin{array}{c}33(33.7) \\
0.54(0.33-0.88)\end{array}$ & $\begin{array}{c}43(43.9) \\
7.64(4.43-13.16)\end{array}$ & $\begin{array}{c}52(53.1) \\
15.28(8.55-27.30)\end{array}$ & $\begin{array}{c}16(16.3) \\
12.83(4.57-36.06)\end{array}$ \\
\hline $80+$ & $\begin{array}{c}30(30.0) \\
0.64(0.38-1.05)\end{array}$ & $\begin{array}{c}43(43.0) \\
7.37(4.29-12.67)\end{array}$ & $\begin{array}{c}65(65.0) \\
25.11(13.91-45.30)\end{array}$ & $\begin{array}{c}20(20.0) \\
16.45(5.99-45.16)\end{array}$ \\
\hline$p$ & 0.016 & $<0.001$ & $<0.001$ & $<0.001$ \\
\hline
\end{tabular}


Table 5. The outcome of COVID-19 patients by age groups.

\begin{tabular}{|c|c|c|c|c|}
\hline $\begin{array}{l}\text { Age } \\
\text { groups }\end{array}$ & $\begin{array}{l}\text { Treatment } \\
n(\%) \\
\text { OR }(95 \% \mathrm{Cl})\end{array}$ & $\begin{array}{c}\text { Hospitalization } \\
n(\%) \\
\text { OR }(95 \% \mathrm{Cl})\end{array}$ & $\begin{array}{c}\text { ICU } \\
n(\%) \\
\text { OR }(95 \% \mathrm{Cl})\end{array}$ & $\begin{array}{c}\text { Exitus at hospitalization } \\
n(\%) \\
\text { OR }(95 \% \mathrm{Cl})\end{array}$ \\
\hline $\begin{array}{l}\begin{array}{l}18-49 \\
\text { (ref.) }\end{array} \\
\text { (n) }\end{array}$ & $\begin{array}{c}258(77.2) \\
1\end{array}$ & $\begin{array}{c}76(22.7) \\
1\end{array}$ & $\begin{array}{c}2(0.6) \\
1\end{array}$ & - \\
\hline $50-64$ & $\begin{array}{c}97(90.6) \\
2.85(1.42-5.75)\end{array}$ & $\begin{array}{c}61(57.0) \\
4.50(2.84-7.13)\end{array}$ & $\begin{array}{c}1(0.9) \\
1.56(0.14-17.44)\end{array}$ & $\begin{array}{c}2(1.9) \\
1^{*}\end{array}$ \\
\hline $65-79$ & $\begin{array}{c}91(92.8) \\
3.82(1.70-8.61)\end{array}$ & $\begin{array}{c}79(80.6) \\
14.11(8.04-24.76)\end{array}$ & $\begin{array}{c}17(13.4) \\
34.84(7.89-153.83)\end{array}$ & $16(16.3)$ \\
\hline $80+$ & $\begin{array}{c}96(96.0) \\
7.07(2.51-19.85)\end{array}$ & $\begin{array}{c}87(87.0) \\
2.71(12.02-42.93)\end{array}$ & $\begin{array}{c}27(27.0) \\
61.39(14.28-293.97)\end{array}$ & $28(28.0)$ \\
\hline$p$ & $<0.001$ & $<0.001$ & $<0.001$ & $<0.001$ \\
\hline
\end{tabular}

* ref

tion; the OR was 1.90 (95\% CI=1.17-3.09) ( $p=0.009)$. It was observed that the male gender was significantly effective in admission to the ICU, and the OR was found to be 2.59 (95\% CI=1.27-5.30) ( $p=0.009)$.

\section{DISCUSSION}

This study identified the varieties as comorbidities, exposure history, symptoms, prognostic laboratory findings and outcomes between the age-grouped patients referred to the outpatient clinic with suspected or confirmed COVID-19. We found that as patients got older, the risk of having a comorbid disease increased as expected. Diabetes mellitus, chronic heart disease and chronic lung disease were reported as common comorbidities. Exposure history was lower in the 65-79 age group, contrary to $\geq$ the 80 years age group. Living conditions are one of the important factors affecting the rate of exposure and contact with the virus. When symptoms were analyzed, we found that younger patients presented sore throat, anosmia, ageusia and myalgia while older patients presented shortness of breath (Table 3). Age came out to be a contributing factor in the number of hospitalizations and admittance to ICU, which ended up increasing mortality rates.

We found that the risk of having comorbidity had increased with aging. This result correlates with previous studies. Cardiovascular disease, cerebrovascular disease, chronic kidney disease and chron- ic lung disease were the most reported comorbidities $(3,12,13)$.

However, in this study, comorbidities varied in defined age groups, which was a noticeable result. Diabetes mellitus, chronic lung diseases and malignancies were significantly higher at ages between 65 and 79, while chronic heart and neurological diseases were observed in patients older than 80 . Chronic heart diseases are expected to increase with age. Cardiovascular system changes, such as the decrease in heart rate and vascular flexibility that occurs with age and thickening of the vascular wall, increase the risk of circulatory system disease. In our country, $43.8 \%$ of the elderly die due to circulatory system diseases (14).

By March 21, 2020, a curfew was imposed for people over 65 years old to minimize the risk of contact with the SARS-CoV-2 virus. Additionally, their families stopped visiting them. As a result, the exposure history was 73\% lower in the 65-79 years old patient group than the 18-49 years old patient group (Table 2). However, this outcome was invalid for the patients over 80 in our study. We believe the reason for this is the localization of our hospital. Our hospital was in a district where quite a lot of nursing homes were localized. Of the patients over 80, 76 (76\%) were residents of these nursing homes, and most of them had an exposure history, but in the 65-79 age group, only 37 (37.7\%) were living in nursing homes. As a 
result, this age group had a higher rate of contact history. Unfortunately, we could not find an article about this situation in the literature.

Patients with COVID-19 suspicion presented various symptoms in the hospital admission. The most prevalent clinical symptoms were fever, cough, shortness of breath and fatigue. In a recent scoping review to identify the common baseline clinical features of COVID-19, the authors concluded that the most common symptoms were fever, cough, shortness of breath and fatigue. These specified symptoms were resembling in different reviews. However, heterogeneity was pointed in most of the articles by the authors (3). These symptoms are not specific to the disease and are difficult to differentiate. We found that some of the symptoms were determined to be age-specific when we grouped patients by age. Sore throat, loss of smell and taste, headache and myalgia were specific to the 18-49 age group $(p<0.001)$. Shortness of breath was represented 2.31 and 2.79 times higher in the 65-79 years and $\geq 80$ years age group than the 1849 years age group, respectively. Among the HCWs, sore throat was one of the most common symptoms as most of them were aged between 18 and 49. There was no statistical difference in symptom existence, fever, cough and gastrointestinal symptoms between age groups. Liu et al. compared clinical and laboratory findings in 303 COVID-19 patients of different ages. According to their study, fatigue was the most common symptom in the elderly than younger patients. The muscle ache was the most common symptom in middle-aged patients, where chest pain was common in younger patients (9). Bastug et al. reported that patients admitted to ICU were older and shortness of breath and dry cough were significantly higher in these patients. However, they did not specify symptoms by age (13). These data show that especially respiratory distress is detected more common in the advanced age group and affects the prognosis.

When poor prognostic factors were analyzed, CRP, ferritin and D-dimer levels were significantly high in $\geq 65$ age groups. In a previous review, high D-dimer and ferritin levels were associated with hospitalization, an outcome that correlates with the older age groups $(8,15,16)$.
When the patients who received treatment were evaluated, it was observed that more treatment was given to other age groups compared to the 1849 age group. According to the Republic of Turkey Ministry of Health COVID-19 Treatment Guideline, hydroxychloroquine was used as first-line therapy during the evaluation of the patients, while favipiravir required ministry of health approval. As hydroxychloroquine had serious side effects in the 1849 age group, some patients refused the treatment, and in some cases, therapy was not given depending on the general condition of the patients. Furthermore, there had been cases where treatment had to be discontinued because of side effects in advanced age patients. Therefore, the 65-79 years and $\geq 80$ years age groups had treatment higher than the 18-49 age group.

Similar to other studies in the literature, it was observed that hospitalization and ICU admission increased with age, and the result was statistically significant in multivariate logistic regression analysis $(17,18)$.

We found that underlying diseases significantly affected hospitalization and the male gender was significantly effective in admission to the intensive care unit, mirroring earlier studies (17).

Many different causes like chronic heart diseases, Alzheimer's disease, chronic inflammation, metabolic syndrome can lead to ferritin and D-dimer elevation in patients over $65(19,20,21)$. As this age group has comorbidities, it is not easy to connect this situation only to COVID-19. We believe that this situation will be clarified in the future with ongoing studies.

Our study has some limitations. First, as a retrospective study, parameters were obtained from the hospital outpatient admission system filled by the physicians. Second, this study represents findings from the early stage of the pandemic, which can alter over time. However, to our knowledge, this is the first article specifying symptoms according to age groups in our country. Considering that $90 \%$ of COVID patients have the disease outpatient, detailed questioning of the symptoms will facilitate patient management. 
Our findings can be useful to identify the disease in outpatient clinics and speed up the transfer of the patients to pandemic areas. Moreover, specific symptoms can be used in the field (such as schools, factories, nursing homes) to select possible COVID-19 patients and quicken isolation.

Most of the symptoms of COVID-19 are indeed similar to other respiratory virus infections. Nevertheless, some symptoms, like loss of smell and taste, are more specific to COVID. When symptoms were defined according to age groups, respiratory symptoms like shortness of breath were common in older age groups. Younger patients are referred to pandemic outpatients with a sore throat, loss of smell and taste, headache, and myalgia. Due to the increasing need for physicians, doctors from dif- ferent specialties had to work in the fields of the pandemic (outpatient clinics and emergency services). In COVID-19 patients, it is thought that patients present respiratory system symptoms, which sometimes cause misdiagnosis. These age-defined symptoms warn physicians from different specialties who work in pandemic areas and lead them to diagnose COVID-19 with non-respiratory symptoms.

In conclusion, although COVID-19 represents nonspecific symptoms, sore throat, loss of smell and taste, headache and myalgia is more specific to ages between 18 and 49, whereas shortness of breath is more specific to patients over 65 years. Predominant symptoms for age groups can help physicians to differentiate the disease in clinical practice.
Ethical Approval: The Republic of Turkey Ministry of Health and the Ethics Committee of Dokuz Eylül University, School of Medicine approved the study on 15 June, 2020 with the decision number of $2020 / 13-44$.

Informed Consent: N.A.

Peer-review: Externally peer-reviewed

Author Contributions: Concept - O.Ö.E.K., V.A.O., N.Y.; Design O.Ö.E.K., V.A.O., N.Y.; Supervision - O.Ö.E.K., V.A.O., N.Y; Findings - O.Ö.E.K., A.N.Z., G.Ö.Ş.; Materials - A.N.Z., Ö.A., B.B., G.Ö.Ş.; Data Collection and/or Processing - A.N.Z., Ö.A., B.B., G.Ö.Ş., N.Ç.O.;
Analysis and/or Interpretation - O.Ö.E.K., B.B., N.Ç.O., A.Ö.A., Literature Review - Ö.A., N.Ç.O., A.Ö.A.; Writer - O.Ö.E.K., V.A.O.; Critical Reviews - N.Y., A.Ö.A., N.Ç.O.

Acknowledgement: We would like to acknowledge Prof. Dr. Reyhan UCKU, Department of Public Health, Dokuz Eylul University School of Medicine for providing statistical analysis assistance.

Conflict of Interest: The authors declare no conflict of interest.

Financial Disclosure: The authors declared that this study has received no financial support.

in Wuhan, China: A retrospective cohort study. Lancet. 2020;395(10229):1054-62. [CrossRef]

7 Spinato G, Fabbris C, Polesel J, Cazzador D, Borsetto D, Hopkins $\mathrm{C}$ et al. Alterations in smell or taste in mildly symptomatic outpatients with SARS-CoV-2 infection. JAMA. 2020;323(20):208990. [CrossRef]

8 Guan WJ, Ni ZY, Hu Y, Liang WH, Ou CQ, He JX et al. Clinical characteristics of coronavirus disease 2019 in China. N Engl J Med. 2020;382(18):1708-20. [ [rrossRef]

9 Liu X, Lv J, Gan L, Zhang Y, Sun F, Meng B et al. Comparative analysis of clinical characteristics, imaging and laboratory findings of different age groups with COVID-19. Indian J Med Microbiol. 2020;38:87-93. [CrossRef]

10 COVID-19 (SARS-CoV-2 Enfeksiyonu) Erişkin Hasta Tedavisi Rehberi. Bilimsel Danışma Kurulu Çalışması [Internet]. T.C. Sağlık Bakanlığı COVID-19 Bilgilendirme Platformu.(May 7, 2021; cited August 15, 2021). Turkish. Available from: https:// covid19.saglik.gov.tr/TR-66926/eriskin-hasta-tedavisi.html. 
11 COVID-19 [Internet]. CDC web page. (cited August 15, 2021). Available from: https://www.cdc.gov/coronavirus/2019-ncov/ index.html.

12 Macedo MCF, Pinheiro IM, Carvalho CJL, Fraga HCJR, Araujo IPC Montes SS et al. Correlation between hospitalized patients' demographics, symptoms, comorbidities, and COVID-19 pandemic in Bahia, Brazil. PLoS One. 2020;15(12):e0243966. [CrossRef]

13 Bastug A, Bodur H, Erdogan S, Gokcinar D, Kazancioglu S, Kosovali BD et al. Clinical and laboratory features of COVID-19: Predictors of severe prognosis. Int Immunopharmacol 2020;88:106950. [rossRef]

14 Yasli Nufusun Demografik Degisimi. T.C. Aile ve Sosyal Hizmetler Bakanlığı, [Internet] [2020]. [cited 2021 August 15] Turkish. Available from: https://www.ailevecalisma.gov.tr/media/45354/yasli-nufus-demografik-degisimi-2020.pdf

15 Pascarella G, Strumia A, Piliego C, Bruno F, Del Buono R, Costa F et al. COVID-19 diagnosis and management: A comprehensive review. J Intern Med. 2020;288(2):192-206. [CrossRef]

16 Velavan TP, Meyer CG. Mild versus severe COVID-19: Laboratory markers. Int J Infect Dis. 2020;95:304-7. [CrossRef]
17 Jain V, Yuan JM. Predictive symptoms and comorbidities for severe COVID 19 and intensive care unit admission: A systematic review and meta-analysis. Int J Public Health. 2020;65(5):53346. [CrossRef

18 Lian J, Jin X, Hao S, Cai H, Zhang S, Zheng L et al. Analysis of epidemiological and clinical features in older patients with coronavirus disease 2019 (COVID-19) outside Wuhan. Clin Infect Dis. 2020;71(15):740-8. [CrossRef]

19 Goozee K, Chatterjee P, James I, Shen K, Sohrabi HR, Asih PR et al. Elevated plasma ferritin in elderly individuals with high neocortical amyloid-beta load. Mol Psychiatry. 2018;23(8):180712. [CrossRef]

20 Coffernils M, Soupart A, Pradier O, Feremans W, Nève P, Decaux G. Hyperferritinemia in adult onset Still's disease and the hemophagocytic syndrome. J Rheumatol. 1992;19(9):1425-7.

21 Schutte T, Thijs A, Smulders YM. Never ignore extremely elevated D-dimer levels: They are specific for serious illness. Neth J Med. 2016;74(10):443-8. 